\title{
Immune related prognosis biomarkers for outcomes of joint preservation surgery in children with ischemic deformity of the proximal femur (preliminary results)
}

\author{
M.P. Teplenky, M.V. Chepeleva, E.I. Kuznetsova
}

Ilizarov National Medical Research Centre for Traumatology and Orthopedics, Kurgan, Russian Federation

\begin{abstract}
Objective Assess the immune status of children with ischemic deformity of the proximal femur taking into account the treatment outcome. Material and methods Preoperative assessment of the immune status was performed for 16 adolescents with ischemic deformity of the proximal femur. Patients' age was $14.4 \pm 0.45$ years. Immunological parameters of 12 adolescents with satisfactory (group I) and 4 patients with poor (group II) anatomical and functional outcome of surgical treatment were compared. Peripheral blood lymphocyte typing was produced with laser cytometry assay, and $\operatorname{IgA}, \operatorname{IgM}, \operatorname{IgG}, \operatorname{IgE}, \mathrm{IL}-18$, IFN $\gamma$ and circulating immune complexes were quantified with enzyme-linked immunoassay. Results Comparative analysis of preoperative immunological parameters showed statistically significant decline of T-helper cells $\left(\mathrm{CD}^{+} \mathrm{CD}^{+}\right)$, high levels of activated $\mathrm{CD} 3^{+} \mathrm{CD} 25$ and $\mathrm{CD} 3^{+} \mathrm{HLADR} \mathrm{T}$ lymphocytes, low levels of activated NK cells $\left(\mathrm{CD} 8^{\mathrm{dim}} \mathrm{CD} 38^{+}\right)$and $\mathrm{IFN} \gamma$ in group II. Humoral immune parameters indicated to low levels of $\operatorname{IgA}$, IgM, IgG and higher levels of circulating immune complexes in group II relative to group I. Conclusion Preliminary data obtained suggest that cellular and humoral immune deficiency can be associated with unfavorable outcome of joint preservation procedure. Such immunological parameters as T lymphocytes subpopulation, immunoglobulins, circulating immune complexes and IFN $\gamma$ can be used as significant prognostic factors for preoperative planning and postoperative rehabilitation of adolescents with ischemic deformity of the proximal femur.

Keywords: ischemic deformity of the proximal femur, joint preservation procedure, cellular immunity, humoral immunity, IFN $\gamma$ phagocytic activity
\end{abstract}

\section{INTRODUCTION}

Hip dysplasia encompasses a spectrum of abnormal hip development with pathological malalignment of the proximal femur, asphericity, spatial malorientation of the hip, large femoral head and a short femoral neck. These alterations can be associated with clinical presentation of primary or secondary acetabular dysplasia. The combined deformities can result in unstable hip joint, incongruent articular surfaces and lead to progressive arthritis in younger individuals. The best surgical approach and the timing of surgery are still controversial. On the one hand reconstruction of hip joint biomechanics would delay the onset of coxarthrosis $[1,2,3]$. On the other hand reconstructive procedure performed with incongruent articular surfaces is likely to increase risk of progression of irreversible changes in the joint. Important predictors are severity of arthritis and limited range of motion in the joint as measured with physical examination and imaging parameters [4]. Levels of cytokins and immunoglobulins, lymphocyte population and subpopulation have been demonstrated to be affected with progression of arthritis [5, 6, 7, 8, 9].

The objective of the study was to assess the immune status of children with ischemic deformity of the proximal femur taking into account the treatment outcome.

\section{MATERIAL AND METHODS}

Preoperative assessment of the immune status was performed for 16 adolescents with ischemic deformity of the proximal femur. Patients' age ranged from 12 to $16(14.4 \pm 0.45)$ years. There were 12 male and 4 female patients. Inclusion criteria were deformity of the proximal femur and the femoral head caused by Perthes disease, no radiological signs of coxarthrosis, type I and II femoral head dislocation, absence of co-occurring conditions being capable to affect immunological parameters. Exclusion criteria were radiological signs of arthritis with subchondral sclerosis, joint space narrowing, subchondral cysts, deformity of the proximal femur due to septic coxitis or avascular necrosis of different etiology, type III femoral head dislocation, signs of femoroacetabular impingement caused by surgical reconstruction, comorbidity.

The Merle d'Aubigné-Postel rating scale was used for preoperative and postoperative evaluation of hip function. Imaging parameters were examined with radiological classifications of Tönnis, Severin. Deformity of the proximal femur with a short neck, high-riding greater trochanter and pathological 
malorientation of the femoral head were detected in all patients. Acetabular flattening and malorientation were observed in 12 patients. Impaired articular relationships were graded as types I and II. Extra-articular procedures were produced in all cases. Reconstructions of the proximal femur included double transtrochanteric osteotomy added by pelvic osteotomy $(n=12)$. Followup period was 18 to 24 months. All patients showed articular relationships regained and the proximal femur anatomy improved due to reconstructive surgeries. All hips were graded as Severin type IIa and arthritis progressed to type I in four cases. Decline in the mobility relative to the baseline ROM was noted in all cases. Patients were assigned to two groups depending on the anatomical and functional outcome.

Group I consisted of 12 patients with the mean age of $14.7 \pm 0.6$ years diagnosed with type II dislocation $(\mathrm{n}=10)$ and type Iinvolvement $(\mathrm{n}=2)$. Mean preoperative score for pain was $4.2 \pm 0.2$ points, for mobility in the joint, $4.6 \pm 0.2$ points, and for ability to walk, $4.4 \pm 0.15$. Reconstruction of both articular components was performed for 10 patients and two underwent femoral procedure only. Postoperatively, mean score for pain was $5.7 \pm 0.2$ points, for mobility in the joint, $5.25 \pm 0.3$ points, and for ability to walk, $5.4 \pm 0.2$.

Group II consisted of 4 patients aged 13-15 $(14 \pm 0.4)$ years diagnosed with type I dislocation $(\mathrm{n}=2)$ and type II involvement $(\mathrm{n}=2)$. Mean preoperative score for pain was $4.25 \pm 0.2$ points, for mobility in the joint, $4.25 \pm 0.5$ points, and for ability to walk, $4.5 \pm 0.5$. Reconstruction of both articular components was performed for 2 patients and two other patients underwent femoral procedure only. Evaluation of hip function showed deteriorated mobility in the joint relative to the baseline scoring $3.5 \pm 0.5$ points, and insignificant decrease in the mean score for ability to walk measuring $4.25 \pm 0.5$ points. No changes in the mean score for pain was observed measuring $4.25 \pm 0.5$ points. Radiological signs of arthritis with subchondral sclerosis, subchondral cysts and joint space narrowing were seen in the group.

Immunotech monoclonal antibodies (France) were used to measure peripheral blood lymphocyte population and subpopulation with BECKMAN COULTER EPICS XL Flow Cytometer (U.S.A.). Enzyme-linked immunoassay was used for measuring
IgA, IgM, IgG, IgE, IL-18, IFNy and circulating immune complexes with Biotek Instruments ELx808 Absorbance Microplate Reader (U.S.A.) and reagent set (ZAO Vector-Best, Russia). The spontaneous and induced NBT tests were used to quantify neutrophil ability to generate reactive oxygen using the technique described by Park. In the induced test, neutrophils were stimulated with microbiological culture Staphylococcus epidermidis (strain № 9198 «NIIEM» SZO RAMN). Lysosomal enzyme activity of neutrophil phagocytes (myeloperoxidase (MPO), cationic proteins) was measured with cytochemical methods. The Graham Knoll method was used to identify neutrophil MPO and bromophenol blue test was applied to quantify neutrophil cationic proteins with the technique described by M.G. Schubich. Semiquantitative laboratory examinations were used to represent the results as the mean cytochemical coefficient (MCC). The Romanowsky-Giemsa staining of blood films was employed to measure neutrophil extracellular traps (NETs). The technique consisted in calculations of the percentage of neutrophils with the segmentation of the nucleus completed (stages 1a and 1c) and the neutrophils releasing chromatin "nets" into extracellular space (mature NETs) [10]. Phagocytic activity of neurtophils and the percentage of neutrophil extracellular traps were counted using Axio Lab.A 1 light microscope under 100× magnification (Karl Zeiss MicroImaging $\mathrm{GmbH}$, ocular lens $12.5 \times$ ) with immersion.

The results obtained were comparable with those of control group comprising 14 relatively healthy adolescents including 10 males and 4 females aged $14.3 \pm 0.6$ years. Statistical analysis was performed using the tools of AtteStat software and Microsoft Office Excel. Results of the numerical data were expressed as median, first and third quartile. Comparisons between groups were performed with analysis of non-parametric Mann-Whitney $U$ test. Written informed consent for the participation in the research project was obtained from the subject's parent/legally acceptable representative. The study received a favorable opinion from the ethics committee of the Russian Ilizarov Scientific Center for Restorative Traumatology and Orthopaedics Ministry of Health of the Russian Federation.

\section{RESULTS}

There were no statistically significant differences in $\mathrm{CD}^{+}{ }^{+} \mathrm{CD} 19^{-} \mathrm{T}$ lymphocytes and $\mathrm{CD}^{-} \mathrm{CD} 19^{+}$ B lymphocytes between the groups (Table 1). Statistically significant decrease in natural killer cells $\left(\mathrm{CD}^{-}{ }^{-} \mathrm{CD} 16^{+} \mathrm{CD}^{-} 6^{+}\right)$, level of IL-18, higher level of IgE, spontaneous NBT test, MPO, cationic proteins and NETs relative to controls were observed in both groups as compared to control group (Tables 2, 3, 4). Levels of IgA and IgG were higher in group I than in control group. Patients of group II showed lower proportion of $\mathrm{T}$ helper cells $\left(\mathrm{CD} 3^{+} \mathrm{CD} 4^{+}\right)$, higher percentage of $\mathrm{CD}^{+} \mathrm{CD}^{+} \mathrm{T}$ lymphocytes, higher 
proportion of $\mathrm{T}$ lymphocytes with $\mathrm{T}$ cell activation markers CD25 and HLADR, lower proportion of activated $\mathrm{NK}$ cells $\left(\mathrm{CD} 8^{\mathrm{dim}} \mathrm{CD} 38^{+}\right)$, lower levels of immunoglobulins of primary classes and induced NBT test as compared to those in controls. Comparative analysis of cellular immunity in groups I and II revealed statistically significant decrease in $\mathrm{T}$ helper cells $\left(\mathrm{CD}^{+} \mathrm{CD}^{+}\right)$, higher percentage of cytotoxic $\mathrm{T}$ lymphocytes $\left(\mathrm{CD}^{+} \mathrm{CD}^{+}\right)$, higher proportion of activated $\mathrm{T}$ lymphocytes $\left(\mathrm{CD} 3{ }^{+} \mathrm{CD} 25\right.$ and $\mathrm{CD}^{+} \mathrm{HLADR}, \mathrm{CD} 8^{\text {bright }} \mathrm{CD} 38^{+}$), lower proportion of activated NK cells $\left(\mathrm{CD} 8^{\mathrm{dim}} \mathrm{CD} 38^{+}\right)$and lower level of IFN $\gamma$ in group II. Evaluation of humoral immunity parameters showed decreased concentration of IgA, IgM, IgG and higher proportion of circulating immune complexes (CIC) in group II relative to group I. There were significant differences in induced NBT test with lower values recorded in group II.

Table 1

Cellular immunity parameters

\begin{tabular}{|c|c|c|c|c|}
\hline \multicolumn{2}{|l|}{ Parameter } & $\mathrm{I}$ & II & Control group \\
\hline \multirow{2}{*}{ T lymphocytes $\mathrm{CD}^{+} \mathrm{CD} 19^{-}$} & $\%$ & $78.8(76.8-80.0)$ & $75.7(73.1-79.0)$ & $71.0(68.4-73.6)$ \\
\hline & $10^{9} / \mathrm{L}$ & $1.57(1.32-1.76)$ & $1.21(1.19-1.71)$ & $1.46(1.33-1.67)$ \\
\hline \multirow{2}{*}{$\mathrm{T}$ helpers $\mathrm{CD} 3{ }^{+} \mathrm{CD}^{+}{ }^{+}$} & $\%$ & $49.4^{p=0.01}(44.8-51.3)$ & $35.4 *(35.0-36.8)$ & $42.6(41.1-45.5)$ \\
\hline & $10^{9} / \mathrm{L}$ & $0.86^{p=0.039}(0.77-1.0)$ & $0.66 *(0.58-0.84)$ & $0.86(0.82-1.08)$ \\
\hline \multirow{2}{*}{ Cytotoxic T lymphocytes $\mathrm{CD}^{+} \mathrm{CD}^{+}$} & $\%$ & $28.8^{p=0.026}(21.6-32.1)$ & $40.3 *(35.7-44.65)$ & $27.0(25.5-29.17)$ \\
\hline & $10^{9} / \mathrm{L}$ & $0.51(0.41-0.71)$ & $0.7(0.61-0.94)$ & $0.61(0.5-0.7)$ \\
\hline \multirow{2}{*}{ B lymphocytes CD3-CD19+ } & $\%$ & $13.6(12.6-16.5)$ & $14.0(10.3-14.7)$ & $12.6(11.7-15.3)$ \\
\hline & $10^{9} / \mathrm{L}$ & $0.36(0.23-0.4)$ & $0.25(0.17-0.32)$ & $0.27(0.25-0.3)$ \\
\hline \multirow{2}{*}{ Natural killers CD3-CD16 ${ }^{+} \mathrm{CD} 56^{+}$} & $\%$ & $7.0 *(4.0-10.5)$ & $9.0 *(8.5-10.0)$ & $13.5(11.3-16.5)$ \\
\hline & $10^{9} / \mathrm{L}$ & $0.11 *(0.08-0.18)$ & $0.19 *(0.16-0.21)$ & $0.29(0.25-0.36)$ \\
\hline \multirow{2}{*}{$\begin{array}{l}\text { CD3 }{ }^{+} \text {HLADR (delayed activation of } \mathrm{T} \\
\text { lymphocytes) }\end{array}$} & $\%$ & $1.65^{p=0.045}(1.3-1.9)$ & $2.3 *(2.2-2.4)$ & $1.8(1.3-2.17)$ \\
\hline & $10^{9} / \mathrm{L}$ & $0.039^{p=0.049}(0.026-0.046)$ & $0.053 *(0.047-0.06)$ & $.03-0.042)$ \\
\hline \multirow{2}{*}{$\begin{array}{l}\mathrm{CD}^{+} \mathrm{CD}^{2} 5^{+} \text {(early activation of } \mathrm{T} \\
\text { lymphocytes) }\end{array}$} & $\%$ & $1.4^{p=0,044}(1.2-1.8)$ & $2.9 *(2.0-3.8)$ & $1.7(1.3-2.0)$ \\
\hline & $10^{9} / \mathrm{L}$ & $0.041(0.032-0.052)$ & $0.057 *(0.044-0.07)$ & $0.037(0.02-0.04)$ \\
\hline $\mathrm{CD}^{\text {bright }} \mathrm{CD} 38^{+}$ & $\%$ & $2.33^{p=0.027}(1.67-2.57)$ & $4.6(3.0-6.0)$ & $3.26(2.4-3.87)$ \\
\hline $\mathrm{CD} 8^{\mathrm{dim}} \mathrm{CD} 38^{+}$ & $\%$ & $0.82^{p=0.049}(0.54-0.92)$ & $0.42 *(0.38-0.56)$ & $0.89(0.55-1.191)$ \\
\hline Immune regulatory index $\left(\mathrm{CD} 4^{+} / \mathrm{CD} 8^{+}\right)$ & & $1.66^{p=0.02}(1.58-1.88)$ & $0.88 *(0.8-1.08)$ & $1.57(1.48-1.78)$ \\
\hline
\end{tabular}

Note: Tables 1, 2, 3, 4 include P-value as the level of statistical significance for groups I and II; ${ }^{*}$ - statistical significance for control group $(\mathrm{p}<0.05)$.

Table 2

Serum concentrations of IFN $\gamma$ and IL-18

\begin{tabular}{|l|c|c|c|}
\hline \multicolumn{1}{|c|}{ Parameter } & I & II & Control group \\
\hline IFN $\gamma(\mathrm{pg} / \mathrm{mL})$ & $4.8^{p=0.038}(3.49-6.3)$ & $2.0(1.5-2.89)$ & $3.5(2.0-4.8)$ \\
\hline IL-18 $(\mathrm{pg} / \mathrm{mL})$ & $185.6^{*}(155.9-203.17)$ & $208.7^{*}(200.0-217.6)$ & $258,5(235.8-274.2)$ \\
\hline
\end{tabular}

Phagocytic and metabolic activity of neutrophils

\begin{tabular}{|l|c|c|c|}
\hline \multicolumn{1}{|c|}{ Parameter } & I & II & Control group \\
\hline Spontaneous NBT (\%) & $18.0^{*}(14.0-25.7)$ & $17.0^{*}(13.5-18.5)$ & $8.0(7.0-9.0)$ \\
\hline Induced NBT (\%) & $75.0^{p=0.026}(63.0-80.0)$ & $60.0^{*}(60.0-67.0)$ & $80.0(78.0-81.0)$ \\
\hline MI NBT & $3.9^{*}(2.9-4.6)$ & $3.5^{*}(3.25-5.45)$ & $9.3(8.9-10.0)$ \\
\hline MPO (MCC) & $2.8^{*}(2.5-2.9)$ & $2.6^{*}(2.55-2.7)$ & $2.3(2.2-2.4)$ \\
\hline Cationic proteins (MCC) & $2.6^{*}(2.5-2.75)$ & $2.6^{*}(2.55-2.65)$ & $2.15(2.0-2.3)$ \\
\hline NETs (total) (\%) & $5.5^{*}(5.0-8.0)$ & $10.0^{*}(8.0-10.5)$ & $2.0(2.0-3.7)$ \\
\hline Early NETs (stage 1a) (\%) & $4.0^{*}(2.75-5.0)$ & $5.0^{*}(3.5-5.5)$ & $1.0(1.0-2.0)$ \\
\hline Early NETs (stage 1b) (\%) & $1.0(0.0-2.0)$ & $2.0(1.0-2.0)$ & $0.5(0.0-1.5)$ \\
\hline NETs (mature) (\%) & $2.0(1.01-2.0)$ & $2.0^{*}(2.0-3.0)$ & $1.0(0.0-1.0)$ \\
\hline
\end{tabular}

Table 4

Humoral immunity parameters

\begin{tabular}{|l|c|c|c|}
\hline \multicolumn{1}{|c|}{ Parameter } & I & II & Control group \\
\hline $\operatorname{IgA}(\mathrm{mg} / \mathrm{mL})$ & $2.91^{p=0.0072 *}(2.5-3.9)$ & $1.0^{*}(0.84-1.05)$ & $1.52(1.12-1.67)$ \\
\hline $\operatorname{IgM}(\mathrm{mg} / \mathrm{mL})$ & $2.57^{p=0.015}(1.69-3.0)$ & $1.0^{*}(0.9-1.05)$ & $1.6(1.29-2.1)$ \\
\hline $\operatorname{IgG}(\mathrm{mg} / \mathrm{mL})$ & $20.0^{p=0.045 *}(14.75-22.3)$ & $9.8(8.1-12.7)$ & $13.0(10.0-15.1)$ \\
\hline $\operatorname{IgE}(\mathrm{mIU})$ & $13.78^{*}(6.93-22.75)$ & $31.3^{*}(27.6-35.0)$ & $4.2(0.6-7.8)$ \\
\hline $\mathrm{CIC}(\mathrm{CU})$ & $23.0^{p=0.048}(11.0-33.0)$ & $34.0^{*}(31.0-55.0)$ & $18.5(13.25-30.0)$ \\
\hline
\end{tabular}




\section{DISCUSSION}

Recent evidence shows that $\mathrm{T}$ cells and $\mathrm{B}$ cells support osteoclastogenesis and bone destruction [11, 12]. Idiopathic avascular necrosis of the femoral head has been described in association with a functional cellular and humoral deficiency [13]. Non-traumatic osteonecrosis of the femoral head in adult patients was reported to be associated with decreased level of $\mathrm{T}$ lymphocytes due to lower proportions of $\mathrm{T}$ helpers and low level of immune regulatory cells [14]. The percentage of $\mathrm{T}$ lymphocytes was found to have correlations with stages of osteonecrosis featuring the lower the $\mathrm{CD}^{+}$the more severe the pathology [15]. No decline of T lymphocytes count was noted in our series of patients with ischemic deformity of the proximal femur. The group of patients with progressive arthritis showed decreased immune regulatory cell count due to low proportion of $\mathrm{T}$ helpers and higher proportion of cytotoxic $\mathrm{T}$ lymphocytes, and patients with good outcomes had $\mathrm{T}$ lymphocytes subsets being well within acceptable limits of normal.

Lower concentrations of IFN $\gamma$ were observed in patients with poor outcomes as compared to those with favorable outcomes. IFN $\gamma$ is described as a positive osteoblastogenic factor promoting growth and differentiation of osteoblasts through activation of osteogenic factors and inhibiting early osteoclast differentiation $[16,17,18]$. We can suggest that decreased expression of IFN $\gamma$ is an adverse event for patients with avascular osteonecrosis. Both groups demonstrated enhanced release of lysosomal enzymes and generation of reactive oxygen that was in line with literature data [19]. Significant increase in NETs caused by osteonecrosis was noted in both groups as compared to controls. The differences between the groups included lower values of induced NBT test in group II indicating to decreased phagocytic potentials in patients with progressive arthritis.

Increased levels of serum immunoglobulin are reported in patients with Perthes disease [20]. Some studies report higher levels of IgM, normal level of IgG and decreased level of $\operatorname{IgA}$ in Perthes disease, as well as normal immunoglobulin levels following conservative treatment of the condition [21]. Our series showed moderate immunoglobulin activation in group I and deficiency of the humoral immunity in group II.

Primary immune deficiency diseases are known to be an important risk factor for surgical complications and unfavorable outcomes [22]. The severity of these disorders are associated with infectious as well as noninfectious complications [23]. Any type of major surgery can stress the body and suppress the immune system [24]. There are reports describing deviations in baseline immunological parameters and the dynamics during treatment of adult patients with osteonecrosis. Preoperative high levels of IgG, CICs and $\mathrm{B}$ lymphocytes that return to normal are reported in patients underging joint replacement surgery. The authors suggest using these parameters as markers of effective treatment [25]. Although we have not encountered publications reporting primary immune function being comparable with outcomes of surgical treatment performed for adolescents with ischemic deformity of the proximal femur, our findings suggest there is a correlation between the factors.

\section{CONCLUSION}

Our findings suggest that good anatomical and functional outcome of surgical treatment can be provided for patients with normal baseline cellular immunity and moderate activation of the humoral immunity. Changes in the cellular and humoral immunity with $\mathrm{T}$ lymphocytes subset imbalances due to low level of $\mathrm{T}$ helpers $\left(\mathrm{CD}^{+}\right)$and higher proportion of activated $\mathrm{T}$ lymphocytes, lower levels of immunoglobulins of primary classes, higher levels of IgE and CICs, decreased level of IFN $\gamma$ were detected in adolescents with unfavorable anatomical and functional outcomes. The findings suggest that cellular and humoral immune deficiency can be associated with unfavorable outcome of joint preservation procedure. Such immunological parameters as Tlymphocytes subpopulation, immunoglobulins, circulating immune complexes and IFN $\gamma$ can be used as significant prognostic factors for preoperative planning and postoperative rehabilitation of adolescents with ischemic deformity of the proximal femur.

\section{REFERENCES}

1. Makushin V.D., Teplenky M.P., Loginova N.G. Lechenie kombinirovannoi deformatsii proksimalnogo otdela bedrennoi kosti [Treatment of the combined deformity of proximal femur]. Genij Ortopedii, 2007, no. 2, pp. 96-98. (in Russian)

2. Barsukov D.B., Krasnov A.I., Baskov V.E., Pozdnikin I.Iu., Voloshin S.Iu., Baskaeva T.V., Bortulev P.I., Aleksandrenko I.P. Korrigiruiushchaia osteotomiia bedra v kompleksnom lechenii detei s bolezniu Legga-Kalve-Pertesa [Corrective femoral osteotomy in the complex treatment of children with Legg-Calvé-Perthes disease]. Genij Ortopedii, 2017, vol. 23, no. 1, pp. 63-70. (in Russian) DOI 10.18019/1028-4427-2017-23-1-63-70

3. Steppacher S.D., Anwander H., Schwab J.M., Siebenrock K.A., Tannast M. Femoral dysplasia. In: The Adult Hip: Hip Arthroplasty Surgery. $3^{\text {rd }}$ Ed. 3. Vol. 1. Wolters Kluwer Health, 2015. P. 430-434. 
4. Albers C.E., Steppacher S.D., Ganz R., Siebenrock K.A., Tannast M. Joint-preserving surgery improves pain, range of motion, and abductor strength after Legg-Calvé-Perthes disease. Clin. Orthop. Relat Res., 2012, vol. 470, no. 9, pp. 2450-2461. DOI: 10.1007/s11999-012-2345-0

5. Grieshaber-Bouyer R., Kämmerer T., Rosshirt N., Nees T.A., Koniezke P., Tripel E., Schiltenwolf M., Kirsch J., Hagmann S., Moradi B. Divergent Mononuclear Cell Participation and Cytokine Release Profiles Define Hip and Knee Osteoarthritis. J. Clin. Med., 2019, vol. 8, no. 10, pp. 1631. DOI: $10.3390 /$ jcm 8101631

6. Gupta A., Mathur A., Hari Babu K.V., Sharma A.K. Clinical implications and immunological findings of Perthes disease: Review. Int. J. Recent Sci. Res., 2017, vol 8, no. 9, pp. 20351-20354. DOI: http://dx.doi.org/10.24327/ijrsr.2017.0809.0877

7. Adapala N.S., Yamaguchi R., Phipps M., Aruwajoye O., Kim H.K.W. Necrotic Bone Stimulates Proinflammatory Responses in Macrophages through the Activation of Toll-Like Receptor 4. Am. J. Pathol., 2016, vol. 186, no. 11, pp. 2987-2999. DOI: 10.1016/j.ajpath.2016.06/024

8. Gao Y.H., Dong N., Yang C., Li S.Q., Liu J.G., Qi X. Elevated synovial fluid IL-33 and IL-6 levels and cartilage degeneration in stage III osteonecrosis of the femoral head. Technol. Health Care, 2020, vol. 28, no. 2, pp. 203-212. DOI: 10.3233/THC-191811

9. Luneva S.N., Matveeva E.L., Chepeleva M.V., Gasanova A.G., Spirkina E.S. Vzaimosviaz belkovogo spektra i immunoglobulinov raznykh klassov $\mathrm{v}$ sinovialnoi zhidkosti pri gonartroze [The relationship between the protein spectrum and immunoglobulins of different classes in the synovial fluid in gonarthrosis]. Klinicheskaia Laboratornaia Diagnostika, 2010, no. 2, pp. 21-23. (in Russian)

10. Andriukov B.G., Somova L.M., Drobot E.I., Matosova E.V. Zashchitnye strategii neitrofilnykh granulotsitov ot patogennykh bakterii [Protective strategies of neutrophilic granulocytes against pathogenic bacteria]. Zdorove. Meditsinskaia Ekologiia. Nauka, 2017, no. 1 (68), pp. 4-18. (in Russian) DOI: 10.5281/zenodo.345606

11. Lurati A., Laria A., Gatti A., Brando B., Scarpellini M. Different T cells' distribution and activation degree of Th17 CD4+ cells in peripheral blood in patients with osteoarthritis, rheumatoid arthritis, and healthy donors: preliminary results of the MAGENTA CLICAO study. Open Access Rheumatol., 2015, vol. 7, pp. 63-68. DOI: 10.2147/OARRR.S81905

12. Weber A., Chan P.M.B., Wen C. Do immune cells lead the way in subchondral bone disturbance in osteoarthritis? Prog. Biophys. Mol. Biol., 2019, vol. 148, pp. 21-31. DOI: 10.1016/j.pbiomolbio.2017.12.004

13. Giraldi E.A., Johnson J., Tcheurekdjian H., Hostoffer R.W. Jr. Idiopathic avascular necrosis associated with humoral deficiency. Ann. Allergy Asthma Immunol., 2017, vol. 118, no. 4, pp. 506-507. DOI: 10.1016/j.anai.2017.01.003

14. Tao J., Dong B., Yang L.X., Xu K.Q., Ma S., Lu J. TGF- $\beta 1$ expression in adults with non-traumatic osteonecrosis of the femoral head. Mol. Med. Rep., 2017, vol. 16, no. 6, pp. 9539-9544. DOI: 10.3892/mmr.2017.7817

15. Ma J., Ge J., Gao F., Wang B., Yue D., Sun W., Wang W. The Role of Immune Regulatory Cells in Nontraumatic Osteonecrosis of the Femoral Head: A Retrospective Clinical Study. Biomed. Res. Int., 2019, vol. 2019, pp. 1302015. DOI: 10.1155/2019/1302015

16. Maruhashi T., Kaifu T., Yabe R., Seno A., Chung S.H., Fujikado N., Iwakura Y. DCIR maintains bone homeostasis by regulating IFN- $\gamma$ production in T cells. J. Immunol., 2015, vol. 194, no. 12, pp. 5681-5691. DOI: 10.4049/jimmunol.1500273

17. Tang M., Tian L., Luo G., Yu X. Interferon-Gamma-Mediated Osteoimmunology. Front Immunol., 2018, vol. 9, pp. 1508. DOI: 10.3389/ fimmu.2018.01508

18. Croes M., Öner F.C., Van Neerven D., Sabir E., Kruyt M.C., Blokhuis T.J., Dhert W.J.A., Alblas J. Proinflammatory T Cells and IL-17 stimulate osteoblast differentiation. Bone, 2016, vol. 84, pp. 262-270. DOI: 10.1016/j.bone 2016.01.010

19. Zakharova N.V., Dorovskikh V.A., Borozda I.V. Rol oksidantnogo stressa v vozniknovenii bolezni Legga-Kalve-Pertesa.Osnovnye kontseptsii patogeneza, diagnostiki i lecheniia (obzor literatury) [The role of oxidative stress in the onset of Legg-Calvé-Perthes disease. Basic concepts of pathogenesis, diagnosis and treatment (Review of the literature)]. Iakutskii Meditsinskii Zhurnal, 2011, no. 4 (36), pp. 95-99. (in Russian)

20. Joseph B. Serum immunoglobulin in Perthes disease. J. Bone Joint Surg. Br., 1991, vol. 73, no. 3, pp. 509-510. DOI: 10.1302/0301-620X.73B3.1670460

21. Iumaguzin U.U., Davletshin R.I., Psianchin T.S. Vliianie sanatorno-kurortnykh faktorov detskogo sanatoriia «Krasnousolskii» na rezultaty lecheniia bolezni Pertesa u detei [Influence of sanatorium-resort factors of "Krasnousolskiy" children's sanatorium on the results of Perthes disease treatment]. Permskii Meditsinskii Zhurnal, 2008, vol. 25, no. 5, pp. 23-28. (in Russian)

22. Pagovich O.E., Lebastchi A.H., Romberg N. Peri-operative considerations in the patient with primary immune deficiency: a review. Surg. Infect. (Larchmt.), 2014, vol. 15, no. 6, pp. 672-678. DOI: 10.1089/sur.2013.196

23. El-Bohy M., Poowuttikul P., E. Secord. Humoral Immune Deficiencies of Childhood. Pediatr. Clin. North Am., 2019 , vol. 66, no. 5, pp. 897-903. DOI: $10.1016 /$ j.pcl.2019.06.010

24. Khaitov P.M., Pinegin B.V. Izmenenie immuniteta pri khirurgicheskikh vmeshatelstvakh [The immunity change in surgical interventions]. Annaly Khirurgicheskoi Gepatologii, 1998, vol. 3, no. 2, pp. 100-110. (in Russian)

25. Chekushkin A.V., Safronov A.A., Safronov Al.A., Matiiash A.M. Dinamika pokazatelei gumoralnogo immuniteta u patsientov s asepticheskim nekrozom golovki bedrennoi kosti [The dynamics of humoral immunity values in patients with aseptic necrosis of the femoral head]. Rossiiskii Immunologicheskii Zhurnal, 2017, vol. 11, no. 3. Temat. Vyp. «XIV Konferentsiia immunologov Urala» [Special issue "XIV Conference of the Urals immunologists"], pp. 555-557. (in Russian)

Received: 07.05.2020

\section{Information about the authors:}

1. Mikhail P. Teplenky, M.D., Ph.D.,

Ilizarov National Medical Research Centre for Traumatology and Orthopedics, Kurgan, Russian Federation, Email: teplenkyMP@mail.ru

2. Marina V. Chepeleva, M.D., Ph.D.,

Ilizarov National Medical Research Centre for Traumatology and Orthopedics, Kurgan, Russian Federation, Email: vladi-2000@hotbox.ru

3. Elena I. Kuznetsova,

Ilizarov National Medical Research Centre for Traumatology and Orthopedics, Kurgan, Russian Federation, Email: citoz@mail.ru 